\title{
3. 老年期の痴呆一医療と介護の現況と発症機構研究の到達点
}

\author{
司会 三重大学神経内科 葛原 茂樹 \\ 司会 慶應義塾大学内科 福内 靖男
}

\section{司会者のことば}

老年期の痴朵性疾患への取り組みは, 高齢社 会を迎える 21 世紀のわが国の医療が直面してい る最大の課題の一つである。 2000 年には約 150 万人であった疾呆性老人数は, 30 年後には約 300 万人に達すると推定されている．実際に，2000 年 4 月から始まった介護保險の利用者の疾患内 訳では, 痴呆性老人一特にアルッハイマー病患 者が多くを占め, その対応と介護は高龄社会の 医療と福祉に共通したテーマでもある.

本シンポジウムでは, 老年期の痴呆性疾患の 研究と医療実践の両面から最新のテーマを取り 上げる，疫学研究においては，地域住民におけ る痴朵と原因疾患の頻度, 臨床診断と病理診断 の一致率を明らかにし, 生活習慣との関連で, 脳血管性痴呆とアルツハイマー病のそれぞれに ついて, 疫学的にリスクを明らかにして子防法 を確立することが課題である．痴呆の臨床につ いては，老年期の痴呆性疾患の双壁である脳血 管性痴呆とアルッハイマー病について, 共通点, 相違点, 早期診断, 治療, リスクと予防が課題
である，脳血管性痴呆については生活習慣病と して予防法と治療法が確立されつつあるが，ア ルッハイマー病については, 近年の対症的治療 薬の登場により早期診断の重要性が増し, 発症 前段階としての軽症認知障害 (MCI : mild cognitive impairment）が注目されている.

アルッハイマー病発症の分子機構研究は現在 最も発展の著しい分野である. 特にアミロイド

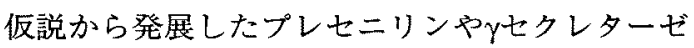
の脳内生理機能の解明を通じて, $\beta$ アロロイドワ クチンや新しい治療薬が開発されつつある。こ のような未来の治療薬開発と並んで, 臨床と介 護の現場では, 痴呆性老人と家族のQOLを向上 させる介護方法とリハビリテーションの整備が 求められている.

本シンポジウムでは, 痴呆に関する最新の知 見を, 疫学, 臨床, 分子生物学的研究, 介護之 リハビリテーションの観点から解説していただ き, 現況と将来の展望について討論していただ く予定である.

\section{1）痴呆の疫学調査一久山町研究から}

九州大学第二内科 清原裕

わが国をはじめとする先進諸国では，高齢人 ロが急速に伸びてその対策が大きな課題となっ
ている、なかでも老年期痴呆は, 高齢者にみら れる精神疾患のなかで最も頻度が高く, その治 
療や介護に多くの労力・経济的負担がかかるこ とから，大きな医療・社会問題として注目を集 めている，予防・治療・介護を含む老年期痴呆 の総合的な対策を講じるには，地域住民を対象 とした長期にわたる疫学研究によって, 一般社 会における痴呆性疾患の赛体を把握し，その要 因を明らかにする必要がある。

福岡県久山町では，40歳以上の住民を対象に 脳卒中をはじめとする心血管病の疫学調查（久 山町研究）が長年にわたり進行中である. 久山 町は, 福岡市に隣接する人口約 7.500 人の都市近 郊型の半農村地域で, 人口・職業構成, 栄養摄 取状況は全国の平均レベルにあり，住民は日本 人の典型的な標本集団といえる.われわれは, 1985 年, 1992 年, 1998 年に,この町の高秢者 (65 歳以上) を対象として老年期知朵の有病率調 査を行った。いずれの調査もほほ同じ 2 段階方
式をとり，最初に長谷川式簡易知能スケールを 用いたスクリーニング調査を，次いで痴朵が疑 われる者を対象に柄沢らの老人ボケの診断基準 およびDSMの基準を用いた二次調査を行なった. 各年の受診者数はそれぞれ 887 名（受診率 95 $\%) ， 1,189$ 名 $(97 \%) ， 1,436$ 名 (99.7\%) であっ た.さらに, 痴呆例は詳細な病歴とともに神経・ 理学的所見をとり,頭部CT・MRIによって脳病 变を形態学的に調べた。 また, 全対象者の死亡 例については剖検によって脳病変を病理学的に 検索し, 痴呆病変の有無, 痴呆病型を再評価し た（剖検率 $80 \%$ 以上）。本報告では，この3 集 団の有病率調查および追跡調査の成績を比較し, 痴呆の有病率. 予後の時代的変化, 疾朵の発症 率および危険因子を検討する。さらに病理学的 手法により，痴朵の正確な病型別内訳も再検討 する。

\section{2）脳血管性痴呆の臨床}

\section{(斯)住友病院神経内科 宇高不可思}

1. 脳血管性痴呆（VD）の症候と診断基準 $\mathrm{VD} の$ 症候学的特徵は, 痴呆以外に, 歩行障害, 尿失禁, 偽性球麻疩が早期から出現することで ある.診断基準として, DSM-IV, ICD-10, NINDS -AIREN, ADDTCによるものなどがあるが, こ れら相互の一致率は低い。痴呆を呈してからの 改善はあまり期待できないので，痴呆になる以 前の, 脳血管障害による軽い認知障害の段階で 診断し, 治療を始めるべきとの立場から, vascular cognitive impairement (VCI) の概念が提 唱されている.

\section{VDの多様性とタイプ別分類}

VDは多様な集団で, 病変の大きさ, 部位, 成 囚などにより症候，予後，治療法が異なる，卒 中発作徯に急性発症の痴呆を呈するのは, 主幹 動脈閉塞による大梗塞, 重要な部位の単一梗塞
であり，段階的に進展するものとして，塞栓症 などによる多発性皮質枝領域梗塞, 多発性ラク ナ状態が，また、楥徐進行型として, Binswanger 型VDがある．脳出血やくも膜下出血によるVD もある。

3. VDの治療, 進行の予防, 予後

VDの中核症候の治療は困難で, 脳血管障害, ことに脳梗塞の一次, 二次予防が最も大切であ る. 高血圧，糖尿病，心房細動などの危険因子 のコントロールのほか, 抗血小板薬や抗凝固薬 を必要に応じて使用する.VDには抑うつ，せん 妄, 興奮などの合併も多く, 脳循環代謝改善薬, 抗うつ薬，少量の向精神薬などを適宜用いる. 予後は，一般に不良である.

4. 特殊な原因によるVD 特殊な原因による,まれなVDの例として,SLE 
に伴うLibman-Sacks心内膜炎より多発性塞栓性 梗塞を生じた例, B細胞性悪性リンパ腫が脳表の 血管周囲腔に充満し，広範な白質梗塞を生じた 例, Sneddon症候群による多発性微小梗塞例を呈 示する。
5. VDとアルツハイマー型痴朵の関連 近年話題になっているアルツハイマー型痴呆 の血管性要因および混合型痴呆の問題について 述べる.

\section{3）アルツハイマー病の臨床}

\section{筑波大学大学院人間総合科学研究科病態制御医学専攻精神医学 朝田隆}

アルツハイマー病（以下ADと略）の臨床経過 は初期，中期，後期の 3 期に分類されるのが常 だった。最近では前臨床期あるいは極早期が注 目されている.

従来のADの臨床研究では,概して家族など周 囲の人が初めて異常に気付いた時点をもって発 症時としていた.その時点からDSM-IVなど国際 的に頻用される診断基準を満たす迄には普通は 年単位の間隔がある。しかも最近では，そうし た発症の 10 年も前に本疾患に特徽的な病理学的 所見が既に存在することがわかっている.

その一方でアミロイドへのワクチン療法や $\beta$,

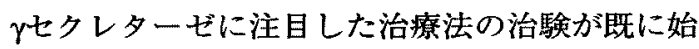
まっている。こうした治療を行うには可及的早 期に精緻な診断をすることが不可欠である。

以上の上うな背景があって, 前臨床期が注目 されるようになったのである。

記憶の過程は記銘, 保持, 想起の 3 要素から
成る。臨床経過において早期では，これら 3 要 素のうち記銘の障害があっても他は比較的良好 であることが特徴的である。

進行とともに記憶の各要素に障害が及ぶばか りでなく，宩症状など他の認知機能の障害も加 わる。また幻覚や妄想などがみられることも多 い. 中期を特徴付けるのはこうした精神症状や 暴力・徘䧃といった問題行動群である、痴呆の 中核症状である認知機能ではなく，この精神症 状・問題行動のゆえに在宅介護は困難となる.

後期には認知機能障害が進行し続けるばかり でなく，余病の併発や転倒・骨折によって心身 ともに衰えが日だってくる。與下機能も低下し て，誤嬹性肺炎や窒息を起こしやすくなる。こ うした呼吸器感染症や尿路感染の繰り返しに伴っ て四肢の屈曲拘縮が進み，寝たきり状態になる。 $\mathrm{AD}$ 患者の死因としてはこうした感染症が多いが, 悪性腫瘍や虚血性心疾患も少なくない。

\section{4）アルツハイマー病の分子機構}

\section{東京大学大学院薬学系研究科臨床薬学教室 岩坪 威}

アルツハイマー病 $(\mathrm{AD})$ に特徽的な病理学的

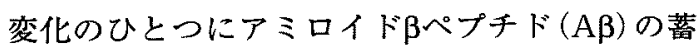
積がある. $\mathrm{A} \beta$ の産生と蓄積を $\mathrm{AD}$ 発症の原因と考 える「及アミロイド仮説」を支持する知見として,
（1） $\mathrm{A} \beta$ 蓄積は $\mathrm{AD} に$ 特異的な変化であること，

（2）びまん性老人斑としてのA 蓄積が $\mathrm{AD}$ 最初 期病変であること, などが重視されてきた，演 者らは細胞が産生するA 
端長が標準型（A $\beta 40 ） よ り も 2$ 残基長く，凝集 性の高いA $\beta 42$ に注目し, $\mathrm{A} \beta 42$ がAD脳に初期か ら優位に蓄皘することを示した。また家族性 $\mathrm{AD}$ の原因遺伝子として同定された $\mathrm{A} \beta$ の前駆体 $\mathrm{APP}$ 及びpresenilin (PS) 1, 2 の変異はいずれも A 42 の産生元進を招くことを示した。これらの結 果は病理学及び遺伝学的見地から $\beta$ アミロイド仮 説を支持し,遗伝歴のない孤発性ADにおいても $\beta$ アアロイドが病因的に作用することを強く予想 させるものであった。さらに最近多数回膜貫通 蛋白であるPSがAßの切り出しを担う $\gamma$-secretase そのものである可能性, $\gamma$-secretase活性はPS
が他の必須因子とともに形成した高分子量複合 体によって担われる可能性が示されつつあり， 細胞膜内でペプチド結合を切断するというユニー クな活性をもつ $\gamma$-secretaseの本態が明らかにされ ようとしている.また とする治療法としてその産生をブロックする $\beta$, $\gamma$-secretase阻害荗, $\beta$ アミロイドに抗A $\beta$ 抗体を結 合させ,その除去を促進するAßペプチドワクチ ン療法などが試みられようとしている．本講演 ではもう一つの蓄積分子である夕ウと $\mathrm{A} \beta$ 関係, $\mathrm{A} \beta$ 以外のアミロイド構成成分などについても言 及しつつ, $\mathrm{AD}$ 分子病態研究の最前線に迫りたい。

\section{5）痴呆性老人の介護・リハビリテーションと介護保険}

\section{医療法人藤本クリニック 藤本 直規}

急増する痴呆老人への対策として 2000 年 4 月 から開始された介護保険のもとで,「介護は社会 全体で支えるという共通認識の定着」「サービス の選択権など利用者の権利確保」「利用者・医療・ 福祉の連携役となるケアマネージャ一の新設」 「サービス事業参加機会の拡大」が推進され，そ れにともない, 特別養護老人ホーム, 老人保健 施設, デイサービスセンターの増設, 最近注目 されている宅老所・ダループホームの新設など, 多くの福祉サービスの基盤整備が加速されてい る。また，ケアマネージャーによって作成され るケアプランによって，これらの福祉サービス の有効的かつ効率的な連携が図られようとして いる.

一方, 痴朵患者に対する医療のかかわりをみ ると, 多くの高齢者が受診している地域の診療 所と一般病院では, 痴呆患者の診断, 診断後の 役割分担，痴呆患者の入院での治療・看護体制 の充実, 介護者への指導, 福祉との連携などが 十分には行われてこなかった。しかし，介護保
険の要介護認定の際に主治医意見書を書く必要 性もあり，かかりつけ医を中心に，痴朵につい ての理解を深めるとともに，デイケアや訪問診 療を行うことで，痴呆患者に対する在宅医療を 支えようとする動きが加速している．

今後さらに改善の余地はあるとしても, 痴呆 ケアシステムの制度の骨格がほほ出来上がった 現在, 医療・保健・福祉を問わず専門職に求め られるのは, 痴呆という疾患の特徴や痴呆患者 や介護者の扔かれている状況とニーズに対する 理解を深め，それぞれの分野のサービスの質の 向上を図ることである．具体的には，「早期診断」 のためにかかりつけ医が専門医との連携を深め ること, 訪問看護の役割を見直すこと、デイサー ビスや入所施設での個別ケアの質を向上させる こと, ショートステイのあり方を再考すること， 介護者への支援体制を充実することなどである. 痴呆患者と介護者のQOL（生活の質）を高める という梘点に立って，新たな痴呆ケアを英知を 集めて作り上げていくことが必要である. 